Instructions for authors, subscriptions and further details:

http://brac.hipatiapress.com

\title{
Cossos en Reclusió i Cavant. Experiències i Representacions Emblemàtiques sobre la Persona.
}

Jordi Morell ${ }^{1}$

1) Facultad de Bellas Artes, Universidad de Barcelona. España

Date of publication: October $3^{\text {rd }}, 2017$

Edition period: October 2017- January 2018

To cite this article: Morell, J (2017). Cossos en Reclusió i Cavant.

Experiències i Representacions Emblemàtiques sobre la Persona.

Barcelona, Research, Art, Creation, 5(3) 272-296. doi:

10.17583/brac.2017.2269

To link this article: http://dx.doi.org/10.17583/brac.2017.2269

\section{PLEASE SCROLL DOWN FOR ARTICLE}

The terms and conditions of use are related to the Open Journal System and to Creative Commons Attribution License (CC-BY). 
BRAC - Barcelona Research Art Creation. Vol. 5 No. 3, October 2017, pp. 272-296

\section{Confined and Digging Bodies. Experiences and Iconic Representations about the Person.}

Jordi Morell.

Universitat de Barcelona. (Spain)

(Received: 27 September 2016; Accepted: 14 February 2017; Published: 3 October 2017)

\section{Abstract}

The article explores the relationship of the person with the hole through both literal and metaphorical situations. On the one hand, it points up the body in seclusion and suspended in a time interval, as in the case of the accident at the mine in San José (Chile) or works by artists like J. Wall, G. Schneider or R. Ondák. In this way, opposed feelings evoke the experiences of waiting and/or punishment, which are explanatory of a confined body or a hole. Literature, cinema and art deal with these events from multiple aspects, which become existential allegories about the individual. On the other hand, the act of digging gains prominence as a symbol of work, but also of the absurd. Recalling the ambivalence that may suggest a person making a hole, this article carries out a drift through works by artists of different generations and contexts, such as C. Burden, M. Heizer, F. Miralles, Geliti, S. Sierra, F. Alÿs, M. Salum, X. Ristol or N. Güell. A series of clearly performative or conceptual works, where the act of digging, drilling, burying or unburying become common practices that show the diversity of meanings and intentions.

Keywords: process art, contemporary imaginary, seclusion, digging, hole 
BRAC - Barcelona Research Art Creation. Vol. 5 No. 3, October 2017, pp. 272-296

\section{Cossos en Reclusió i Cavant. Experiències i Representacions Emblemàtiques sobre la Persona.}

Jordi Morell.

Universitat de Barcelona. (España)

(Recibido: 27 setiembre 2016; Aceptado: 14 febrero 2017; Publicado: 3 octubre 2017)

\section{Resum}

L'article indaga en la relació de la persona amb el forat, a través de situacions literals i d'altres de metafòriques. Per una banda, es fa èmfasi al cos reclòs $i$ que es troba suspès en un interval temporal, com va ser el cas de l'accident a la mina de San José (Xile) o en obres d'artistes com ara J. Wall, G. Schneider o R. Ondák. D'aquesta manera, s'evoquen sensacions antagòniques que ens acosten a vivències d'espera i/o de càstig, explicatives d'un cos reclòs o en un forat. La literatura, el cinema i l'art tracten aquests fets des de múltiples vessants, que esdevenen al-legories existencials sobre la persona. Per altra banda, l'acte de cavar pren protagonisme com a emblema del treball, però també de l'absurd. Recordant l'ambivalència que pot suggerir la persona fent un forat, es fa una deriva a través d'obres d'artistes de diferents generacions i contextos, com per exemple C. Burden, M. Heizer, F. Miralles, Gelitin, S. Sierra, F. Alÿs, M. Salum, X. Ristol o N. Güell. Un seguit d'obres clarament performàtiques o de caràcter conceptual, en què el fet de cavar, perforar, enterrar o desenterrar esdevenen pràctiques comunes, alhora que s'evidencien la diversitat de significats i intencions.

Paraules clau: art processual, imaginari contemporani, reclusió, excavació, forat 
i pensem el cos com un receptacle $i$ ho relacionem amb la idea de forat, s'engega una discussió dialèctica entre el dins i el fora. Aquesta discussió pot desencadenar una mena de mise en abîme, que produeix imatges d'espai dins d'espai, de cos dins de cos, i que esdevé una situació de simultaneïtat entre interior i exterior. Cos i forat ens remeten, per un costat, a una mena de joc de nines russes de multinivells i, per l'altre, a una metàfora que fa referència a la mateixa existència humana.

Georges Perec escriu que viure és passar d'un espai a un altre fent el possible per no colpejar-se (Perec, 2004, p. 25). De fet, el llibre Especies de espacios, de Perec, a través de l'experiència vivencial i la quotidianitat, ens interpel·la sobre la relació del cos amb l'espai. Aquest espai és fractal i està format per «trossos petits d'espais», encara que, segons l'escriptor, l'objecte principal del llibre no és el buit, sinó més aviat el que hi ha al voltant o a dins. Destaco les reflexions que en fa en el capítol dedicat a l'apartament, especialment quan Perec pensa en la cambra inútil: "una pieza inútil, absoluta y deliberadamente inútil" (Perec, 2004, p. 59). Posant al límit el llenguatge, exposa la impossibilitat de parlar del buit sense fer referència a alguna cosa. Perec remarca que no pensava en espais inutilitzables, ni inutilitzats, sinó simplement en els que fossin inútils. En aquest sentit, pensar el forat és fer referència a una multitud de forats, els quals inevitablement evoquen el buit, com també fan referència al que hi ha al seu voltant o a l'interior, amb fortes càrregues simbòliques a causa de la seva utilitat o la seva raó de ser. Per això també he estat temptat de pensar en un forat realment inútil.

La persona dins un forat és metàfora de determinades situacions existencials $\mathrm{i}$ és recurrent en obres literàries, cinematogràfiques o en peces d'artistes de diferents disciplines. Un exemple n'és la novel·la La mujer de la arena $^{1}$, de Kôbô Abe (1989), que ens ofereix una al·legoria de l'existència mentre reflexiona sobre l'alienació de l'ésser humà. L'escriptor narra la història d'un entomòleg que vaga pel desert a la recerca d'insectes per a la seva col-lecció, amb la voluntat de ser reconegut almenys per la seva tasca. El protagonista és acollit en un poblat i passa la nit en una estranya casa situada a l'interior d'un forat on viu una dona. L'endemà, l'entomòleg s'adonarà que ha caigut en una trampa i que, retingut sota la seva voluntat, haurà d'ajudar la dona a cavar i sostreure l'arena que contínuament condemna la casa a ser sepultada. L'ambient asfixiant bé donat tant per l'absència d'aigua en el relat com per l'atmosfera arenosa, que evoca la soledat metafísica i el destí de l'home. 
El forat com a trampa, com el que habiten els protagonistes de La mujer de la arena, remet a la impossibilitat de fuga. Aquesta metàfora recorda les paraules de Sloterdijk quan afirma que l'home és una forma de vida aporètica, sense sortida, que sent, a la vegada, que ha de fer alguna cosa amb si mateix per suportar aquesta falta de sortida. I adverteix que "si existir significa caer en la trampa, también significa habitar la trampa como mundo" (Sloterdijk, 2008, p. 59).

La trampa també és present en el conte La guarida, de Kafka (2000). L'escriptor descriu, des de la perspectiva d'un animal, com es forma un sistema subterrani de passadissos que recorden una presó de màxima seguretat, amb l'obsessió del perfeccionisme agònic. Aquí el cau és, alhora, un refugi segur i un espai d'amenaça d'un possible atac extern. Perquè pensar el cos dins un forat pot evocar la sensació de benestar i de refugi, però també d'ansietat i d'opressió, de sepultura i d'empresonament. Per tant, sensacions oposades es barregen: la protecció i la seguretat amb la claustrofòbia, l'angoixa en un espai tancat, la manca de mobilitat i de llibertat. El fet d'estar en un forat fàcilment ens pot remetre a les presons i a altres espais de confinament on es reté la persona contra la seva voluntat: des de la cel·la, la cambra o el zulo, a altres formes de reclusió col·lectives o en massa.

He terminado la guarida y parece que ha quedado bien. Desde fuera sólo se puede ver un gran agujero, pero éste, en realidad, no conduce a ninguna parte; después de un par de metros se levanta una pared rocosa natural. No quiero preciarme de haber ideado esa artimaña, son los restos de uno de los muchos intentos de excavación frustrados. Tras meditar sobre ellos, creí finalmente que sería ventajoso no tapar el agujero. Hay algunas artimañas tan finas que terminan matándose a sí mismas, eso lo sé mejor que nadie, y también resulta audaz llamar la atención con este agujero, pues se puede pensar que aquí hay algo digno de ser investigado. Pero no me conoce quien cree que soy cobarde y que mi obra es producto de mi cobardía. A la distancia de unos mil pasos se encuentra, oculta por una capa de musgo que se levanta, la entrada de la guarida. (Kafka, 2000, p. 385)

\section{Cos Reclòs}

Situacions límit, crues i absurdes tenen lloc al voltant de forats, tal com hem vist anteriorment amb la novel-la de Kôbô Abe o el conte de Kafka, i esdevenen al·legories existencials sobre la persona. Fàcilment, com apuntàvem abans, en trobem exemples que narren o mostren situacions 
paradigmàtiques en la literatura, el cinema i en obres d'artistes contemporanis. A més, sovint es retroalimenten o es referencien les unes amb les altres. Per exemple, una obra que recorda el cau del personatge kafkià és The Burrow (2004), de Jeff Wall. A part del títol homònim al de la novel·la, aquesta fotografia "documental" de Wall mostra un forat excavat en un solar o descampat abandonat, que ha estat marcat i protegit per uns taulons de fusta, de manera que es crea un rectangle negre al centre. No sabem la funció del forat ni el seu origen, però el títol evoca l'hàbitat d'alguna criatura (Newman, 2007, p. 140).

The Well (1989), The Drain (1989) i The Flooded Grave (1998-2000) són tres obres més de Jeff Wall en què també és present el forat. Aquestes tres darreres van participar en l'exposició "Unter der Erde. Von Kafka bis Kippenberger", en la qual el conte de Kafka serveix com a punt de partida per tractar l'interès pel món subterrani en obres d'artistes de diferents contextos. Les comissàries exposen que el fet de descendir cap al món subterrani - en búnquers, soterranis, coves, grutes i túnels - ha tingut a veure amb les utopies i antiutopies del segle xx. En aquest punt es podrien afegir les emblemàtiques exploracions del subsòl que va realitzar Gordon Matta-Clark, per exemple a la ciutat de Nova York, recollides en la pel-lícula Substrait: Underground Dailies (1976), o les «expedicions peripatètiques» (Moure, 2006, p. 284) per les clavegueres de París aplegades al film Sous-sol de Paris (1977).

Una altra representació del cos reclòs en la producció de Jeff Wall és l'obra After 'Invisible Man' by Ralph Ellison, the Prologue (1980), en la qual recrea l'espai subterrani on es retira el personatge anònim afroamericà de la novel·la de Ralph Ellison El hombre invisible (1952).

Mi hoyo es cálido y luminoso. Sí, muy luminoso. Dudo que en toda Nueva York haya un lugar más iluminado que este hoyo en el que vivo, y al decirlo no excluyo Broadway, ni tampoco el Empire State Building en una noche soñada por un fotógrafo. (Ellison, 1966, p. 14 citat per Newman, 2007)

La singularitat d'aquesta cambra és la seva lluminositat, encara que en la fotografia de Wall és representada per la gran quantitat de bombetes de tot tipus que pengen del sostre, on només unes quantes emeten llum. I és que en la novel·la de l'home invisible, per contrarestar la seva invisibilitat en la societat reivindica la llum que li dóna forma.

Tots aquests treballs ens recorden que pensar el cos reclòs (o dins un forat) pot evocar sensacions oposades. Des d'una perspectiva més agosarada, la 
major part de l'obra de l'artista alemany Gregor Schneider gira al voltant de cambres que evoquen també la reclusió de la persona, malgrat que hi traspuen fortes sensacions inquietants, d'ansietat i d'opressió. Ell mateix descriu el seu treball com a «construcció $d$ 'habitacions», però la referència principal (sobretot en els primers treballs) no és tant l'espai, sinó la paret: la paret és a la vegada límit, presó i cova (Loers, 2011, p. 71). Cal recordar que l'artista va fer de la seva casa familiar - heretada a la seva ciutat natal el 1985 (Rheydt, regió del Baix Rin) - el suport i el punt de partida de la seva obra artística. Durant els quinze anys posteriors, Schneider va reconstruir radicalment la seva anomenada Haus $u r$, de la qual gairebé només quedà la façana de la seva arquitectura original. L'artista va transformar completament l'interior de l'edifici en una estructura laberíntica, amb habitacions dobles, parets giratòries, portes trampa, forats i finestres falses. A més, va fer que les habitacions estiguessin insonoritzades. D'aquesta manera, es realça l'experiència física de l'espai, al mateix temps que la càrrega psicològica interior. Per a l'espectador, aquest aïllament de la informació sensorial externa evoca un seguit d'associacions i temors.

Volviendo a la paradójica relación biunívoca casa-prisión, parece indudable que Schneider no sólo siente cierta predilección por la idea (ficticia) de encerrar un cuerpo vivo, como en el caso de $u r 8$, Habitación muerta completamente aislada (1989-1991), sino también de infligirle un castigo desmesurado. En dicha obra la configuración formal se establecía como una cámara acorazada en la que se observaban distintas capas de plomo, lana de roca u hormigón, así como los amenazantes pinchos de la gomaespuma insonorizadora, lo que daba lugar a lo que en acústica se denomina habitación muerta o cámara anecoica, un lugar tan sumamente aislado que no deja escapar ningún sonido por fuerte o desgarrador que éste sea. (Moriente, 2011, p. 162)

\section{Forat-cova (Incís)}

Cercant les primeres referències que tenim del cos en relació amb el forat, caldria, inevitablement, fer al·lusió a les necessitats bàsiques de la vida i a la gestió del cos més enllà d'aquesta. Les cavitats naturals d'un terreny, com les coves o cavernes, les grutes i els avencs, formats per processos geològics, han donat aixopluc i refugi tant a animals com a éssers humans, al mateix temps que han estat utilitzats com a espais funeraris per resguardar cossos sense vida. 
Cal dir que les coves, des de finals del segle xix, han captivat els espeleòlegs, que han explorat pràcticament tots els orificis terrestres coneguts amb voluntats científiques - més endavant, s'expandirà cap a fins esportius 0 turístics. La cova se'ns representa com a mite originari, relacionat amb un tipus d'imaginari de tradició romàntica. En aquest sentit, el documental Cave of Forgotten Dreams (2010), del director Werner Herzog, ens acosta a la cova de Chauvet, al sud de França. Herzog i el seu equip documenten els rastres de cultura i vida - pintures rupestres, rastres fossilitzats i empremtes i marques d'animals - de diferents períodes en el seu entorn natural. Una particularitat del documental és que ens mostra un paisatge prohibit, o si més no restringit al públic. El director i el seu equip van aconseguir tenir accés exclusiu per gravar dins de la cova, descoberta el 1994 i considerada una de les més significatives de l'art prehistòric; per evitar-ne la degradació, s'hi va prohibir l'accés. Aquesta decisió va tenir en compte l'error usual de convertir un indret en lloc d'interès turístic massiu poc després de la seva descoberta, amb les evidències demostrades en altres coves i grutes d'interès, com per exemple les coves de Lascaux o d'Altamira.

La tecnologia de les tres dimensions i altres enginys van permetre a l'equip d'Herzog captar unes imatges amb gran profunditat i, amb una construcció pausada, rastrejar l'espai interior de la cova. L'espectador del film esdevé en part explorador, encara que sigui des de la butaca confortable del cinema.

Pel que fa referència a l'exploració del territori i de les situacions que sorgeixen entre natura i cultura, la cova i la tecnologia també van ser presents a l'exposició "Perdre les formes. Segon exercici" (2012) de l'artista Esteve Subirah. En la qual l'artista presentava un grup de peces que, entre altres coses, propiciaven relacions mentals o emocionals amb un paisatge i territori molt propers i familiars per a ell. La Forma núm. 10 (2012) és el resultat d'un «exercici» — com defineix el mateix artista - al voltant del Cau del Duc. Aquest indret assenyalat és una cova, un forat fet a partir de l'erosió de la roca calcària al massís del Montgrí. A part del seu valor històric i de troballes arqueològiques, és un lloc emblemàtic per als habitants dels pobles del voltant, amb múltiples històries i llegendes. L'artista es va traslladar, durant el juny de 2012, amb tècnics especialistes i «aparells d'última generació» per obtenir una digitalització de l'interior del Cau del Duc. A continuació, mitjançant un motlle, construeix una peça compacta de ferro de tot l'interior de la cova. A l'exposició acompanyava l'escultura — que ens recorda pel seu emplaçament les pedres rares exhibides en qualsevol museu de ciències naturals - amb una graella d'imatges del procés de digitalització de l'espai en 
negatiu i un parell de postals de principis del segle passat sobre el lloc en qüestió (vegeu figures 1, 2 i 3).

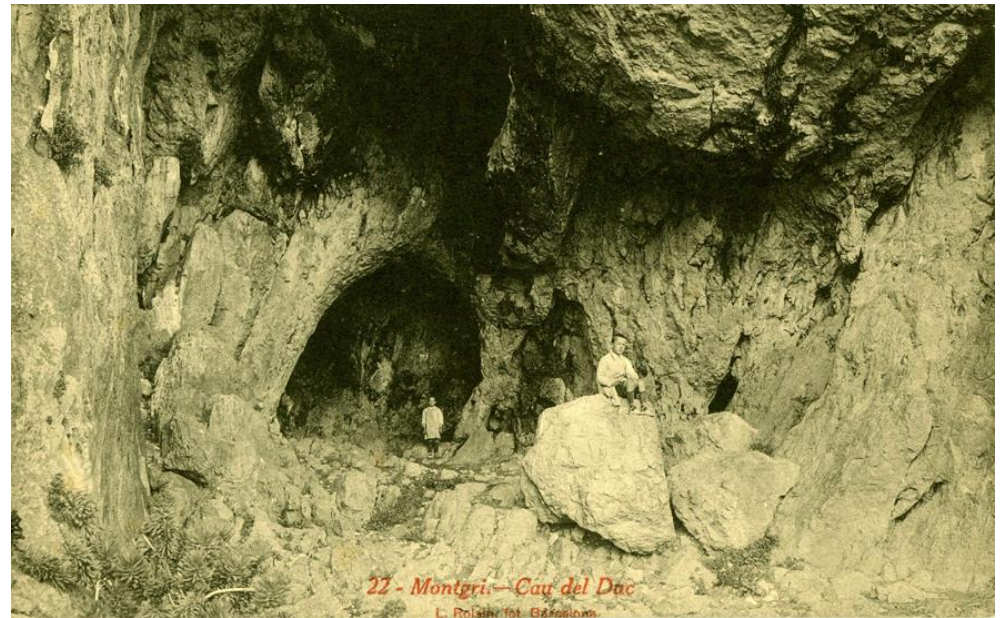

Figura 1. Postal núm. 22, Montgrí. Cau del Duc, Lucien Roisin, 1er terç segle xx. Font: E. Subirah.

L'experiència in situ al Cau del Duc d'Esteve Subirah, amb la producció d'imatges i volums del procés presentats a l'exposició, té la voluntat d'entendre l'espai i els seus límits, a més d'inserir-se a base de rumors en la memòria personal. La seva forma amorfa solidifica, encara que sigui a escala, l'espai buit de la cova.

L'exposició d'Ibon Aranberri “Organigrama”, vista a la Fundació Antoni Tàpies (2011), proposava establir relacions i confrontacions entre diverses sèries de treballs realitzats per l'artista, amb la voluntat d'estimular la resignificació d'obres passades i d'altres fetes a propòsit per a l'exposició. D'aquesta manera, juntament amb treballs com Mar del Pirineo (2006) i Política hidráulica (2004-2010) —dues sèries reconegudes d'Aranberri que indaguen les infraestructures hidràuliques a la península Ibèrica, desenvolupades de manera intensiva les primeres dècades del segle passat $\mathrm{i}$ sobre les alteracions físiques en el paisatge ocasionades per les obres d'enginyeria-, hi trobem (Ir.T.n $\left.{ }^{\circ} 513\right)$ Zuloa. Extended Repertory (20032008). Aquest treball recull la documentació científica, històrica, arqueològica i fotogràfica que l'artista ha recopilat al voltant de la cova d'Iritegi (Guipúscoa). Aquesta cova va ser intervinguda físicament i simbòlicament per Aranberri amb el tancament de l'entrada amb una 
estructura plana i opaca, on hi ha un petit orifici que serveix de pas tant d'entrada com de sortida per a la colònia de ratpenats que hi habita. Per a Aranberri, l'espai de la cova pot ser imaginat clos des de l'obscuritat interior, i des de l'exterior ens proposa una discontinuïtat en el paisatge natural. A part del treball específic in situ, i com a acte de presentació, es va organitzar una excursió col·lectiva a la cova. Així, el vídeo documental de l'esdeveniment, juntament amb dibuixos, mapes i fotografies, formen part del desplegament heterogeni de l'obra.

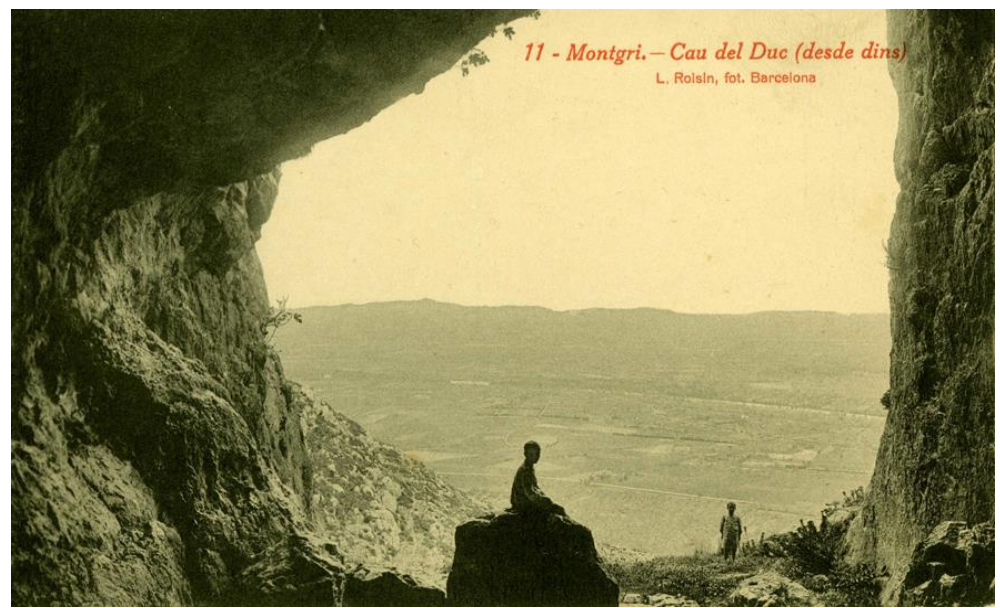

Figura 2. Postal núm. 11, Montgrí. Cau del Duc (des de dins), Lucien Roisin, 1er terç segle xx. Font: E. Subirah.

Però, a part d'aquestes cavitats naturals, hi ha altres forats a tenir en compte, amb intencions similars, que han estat desenvolupats amb unes finalitats més o menys concretes. Si bé podríem pensar en caus, llodrigueres i amagatalls, també les excavacions al subsòl produïdes per l'home han servit tant per refugiar-se de forces adverses —els bombardeigs aeris - com per aconseguir matèries primeres. Així mateix, han estat espais per allotjar el cos dels difunts. En la història de la humanitat trobem un gran assortiment de sepultures i tombes. Són espais bàsicament comuns, des de les tombes antropomorfes megalítiques fins a les que omplen els cementiris actuals, però tenen diferències que rauen en els ritus i que depenen de les creences escatològiques. Finalment, entre altres funcions, també trobem cavitats 
creades per a fosses comunes, que inevitablement ens evoquen fets inhumans del nostre temps.

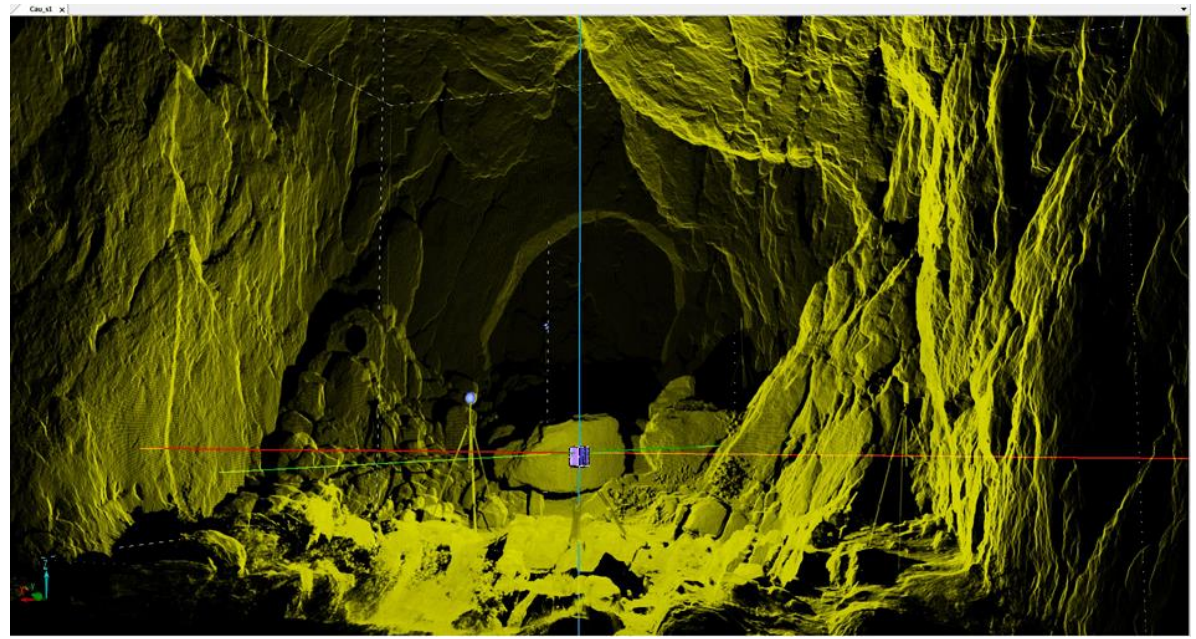

Figura 3. Imatge digital del Cau del Duc, Esteve Subirah, 2012. Font: Imatge cedida per l'artista

\section{Persona sota Terra}

Com s'ha comentat anteriorment, diferents productes culturals ens exhibeixen situacions en què el cos es troba reclòs o atrapat en espais reduïts i asfixiants. Aquestes ficcions o representacions conviuen amb la realitat i el dia a dia que ens mostren els mitjans de comunicació i, en ocasions, se n'autoalimenten.

Per exemple, la pel·lícula Buried (2010), dirigida per Rodrigo Cortés, ens ofereix una experiència límit del cos. El seu protagonista passa enterrat viu vuitanta dels noranta minuts del llargmetratge, amb un mòbil com a única font lumínica i amb un contacte insuficient amb l'exterior. El film dóna pistes del drama que viu el protagonista, Paul Conroy (protagonitzat per Ryan Reynolds), en què destaca la falta d'oxigen com el pitjor obstacle per sobreviure, en una cursa a contra rellotge.

Aquestes escenes ens traslladen a records mediàtics, com els zulos de la dècada dels noranta. Els zulos esdevenen un món a part, hermètic i sense referència cartogràfica. Espais de gran pressió corporal i psíquica on han estat recloses persones amb finalitats polítiques, com és el cas de José Antonio Ortega Lara, funcionari de presons segrestat durant 532 dies. 
Tornant a les produccions cinematogràfiques, fem referència a There Will Be Blood (2007), del director Paul Thomas Anderson, que presenta l'ambient fosc i profund d'una excavació petroliera i les relacions de poder que impliquen els pous de petroli de Califòrnia a principis del segle xx. En els primers minuts del film, domina la negror de les imatges i el silenci estrident de la maquinària, que serà trencat per l'accident laboral que pateix un miner amb conseqüències tràgiques.

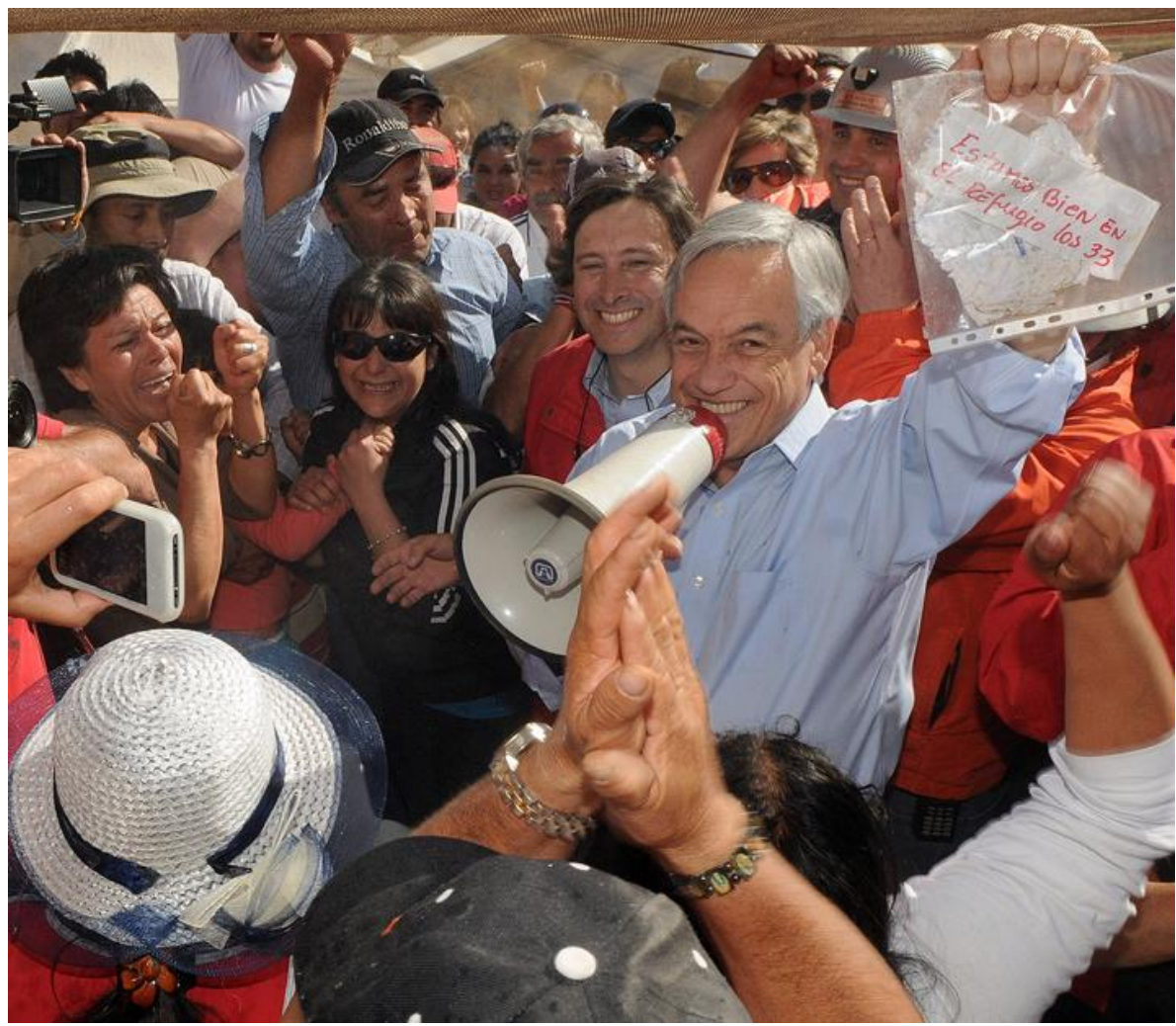

Figura 4. El president Sebastián Piñera fent públic el missatge dels 33 miners (22/10/2010). Font: Gobierno de Chile [CC BY 2.0]. Consultat des de https://commons.wikimedia.org/wiki/File:Mina_San_Jos\%C3\%A9_-Pi\%C3\%B1era _con_mensaje_de_mineros_atrapados.jpg

De fet, i deixant a part el terreny de la ficció, aquests desastres són habituals en aquests tipus de treballs. En els darrers anys, un dels més coneguts va ser l'accident que es va produir el 5 d'agost de 2010, quan un grup de treballadors de la mina de San José de Xile, situada al nord de la ciutat xilena 
de Copiapó, va romandre atrapat durant setanta dies a uns 700 metres de profunditat. La situació inicial d'incomunicació de les víctimes, en un espai sepultat $i$ suspès en el temps, feia inevitable atribuir el rol de cadàver als miners. Al seu voltant, es va organitzar un rescat accelerat per assegurar-ne la supervivència. «Estamos bien en el refugio los 33», deia el primer missatge, escrit en vermell en una fulla de quadern, que van fer arribar els miners després de lligar-lo a una de les sondes, i que més tard va fer públic el president, Sebastián Piñera. El missatge fou seguit d'una explosió mediàtica que va convertir l'accident en un espectable, entre el reality show i la telesèrie, encavallat en la realitat i la ficció, mogut per l'empatia envers la dissort dels miners i el clar oportunisme polític (vegeu figures 4 i 5).

A la 54a Biennal de Venècia (2011), l'artista eslovac Roman Ondák va presentar la instal-lació Time Capsule (2011), en la qual l'espectador es trobava al davant d'una rèplica de la Fénix 2, la càpsula que va ser utilitzada en el rescat laboriós dels trenta-tres miners a través d'un pou perforat per a l'ocasió. A través d'aquest artefacte, l'artista volia remetre a l'espectador les experiències d'aïllament reals viscudes pels miners $i$ els quaranta minuts de trajecte de retorn cap a la superfície, encara que, de fet, el context de la mina s'articuli al voltant d'un descens feixuc a l'interior del subsòl i d'un treball nocturn, precari, que evoca fins i tot el treball forçat i el càstig.

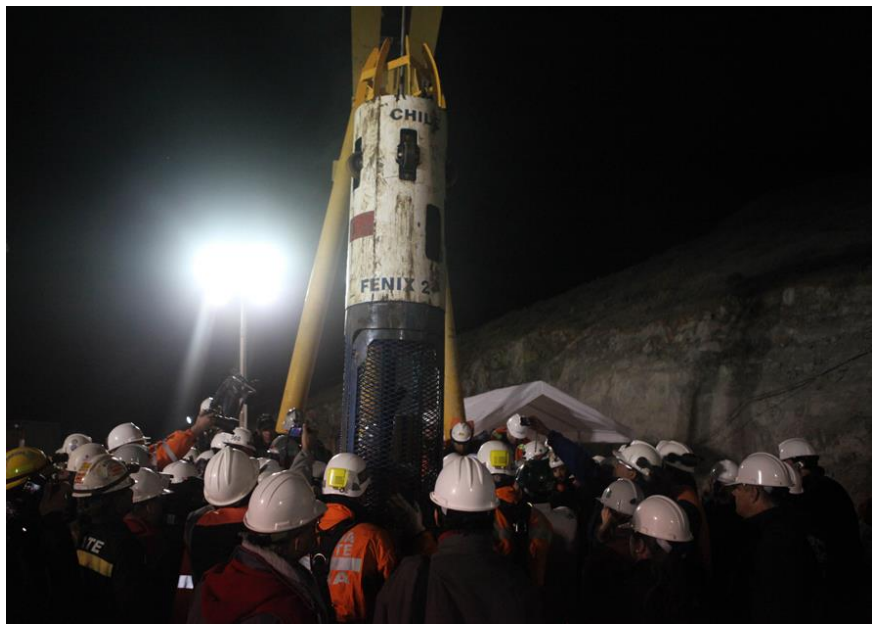

Figura 5. Fotografia del rescat del darrer miner amb la càpsula Fénix 2 (13/10/2010). Font: H. Infante / Gobierno de Chile [CC BY 2.0]. Consultat des de https://commons. Wikimedia. org/wiki/File:Last_rescuers_(5081843488).jpg 


\section{Cavar}

Pollard tiene 42 años. Es un hombre delgado con bigote que nació en Pittsburg y cumplió servicio como soldado raso en el Batallón 352 de Ingenieros en Birmania durante la Segunda Guerra Mundial. Es un operador de maquinaria de grado 10, lo que significa que gana 3,01 dólares por hora. Uno de los últimos en atender a John Fitzgerald Kennedy, quien fuera el presidente número 35 de este país, fue un obrero que cobra 3,01 por hora y dijo que cavar su tumba era un honor. (Breslin, 1963)

Per a l'enterrador que va preparar la tomba de J. F. Kennedy, va ser un honor fer el forat. El senyor Pollard se sentia orgullós d'haver cavat aquell forat que acolliria el cos assassinat del popular president dels Estats Units.

Potser en l'àmbit dels professionals de les funeràries, un personatge a tenir en compte és Thomas Lynch, poeta $\mathrm{i}$ assagista nord-americà i expropietari d'una funerària a Michigan, que va escriure El enterrador (2004), un llibre que tracta el tema de la mort, dels morts i de l'ofici d'enterrar a través de la seva experiència a la funerària. Encara que ell no cava tombes, sí que ens convida a mirar dins el forat. En aquest mateix context, un altre cas amb força punts en comú, encara que el format sigui molt diferent, és la popular sèrie de televisió Six Feet Under (2001-2005), que tracta sobre el dia a dia de la família Fisher, que regenta la funerària Fisher \& Sons a Los Angeles. El títol de la sèrie evoca irònicament la profunditat del cos enterrat, però per al director de la sèrie, Alan Ball, també fa referència metafòricament a les emocions i als sentiments que es mouen sota la superfície de la vida quotidiana.

A l'obra The Flooded Grave (1998-2000) de Jeff Wall, que he citat anteriorment, veiem una tomba rectangular excavada en un cementiri. Quan mirem a l'interior, l'espectador hi troba un paisatge marí: "Donde esperaríamos ver una tumba o un ataúd nos encontramos con una imagen de vida exhuberante" (Newman, 2007, p. 143). Wall, en la imatge, fa visibles espais incompatibles, com si es tractés d'una metàfora. Amb aquesta imatge, juntament amb l'obra The Burrow (2004), se'ns mostren els indicis d'una excavació i funcionen de contrapunt de l'acte de cavar. L'acció és present en una altra obra de Wall, The Well (1989), en la qual trobem en la fotografia una dona a l'interior d'un forat que cava un pou, que és deduït pel títol de la imatge.

Cavar, l'acte, com també el resultat, el forat, són molt presents en pràctiques artístiques de les darreres dècades. I és que dur a terme un forat és evocar temps immemorials, fent conviure el fet més animal i el desenvolupament tècnic més sofisticat. És una acció primària que ha 
acompanyat l'evolució humana. Aquesta acció repetida incansablement ens remet al cau kafkià que sempre es repensa, sempre és incomplet, però també a la història de Kôbô Abe, en la qual els protagonistes estan condemnats a cavar i sostraure l'arena que els amenaça. Les dues històries fan referència a la figura de Sísif, l'heroi absurd, tant per les seves passions com pel seu turment, símbol del treball inútil i sense esperança.

Sísif és la figura del treball inacabable, que es renova cíclicament una vegada $i$ una altra, $i$ ha esdevingut un element d'atracció (contradictòria), en el qual molts artistes s'han interessat d'una manera o altra. Albert Camus, en el llibre El mite de Sísif (1987), analitza la idea d'absurd mentre proposa un trencament amb l'existencialisme que havia tingut fins al moment. En aquest sentit, trobem l'absurditat en qualsevol esforç humà per trobar un sentit a l'univers, fet que acabarà fracassant irremeiablement.

Walter de Maria va realitzar diverses obres que evoquen la noció d'absurditat, com la figura de Sísif. Per exemple, l'obra titulada Boxes for Meaningless Work (1961), que consistia en dues caixes de fusta d'aspecte minimalista i les instruccions d'ús següents: "Traslladar coses d'una caixa a l'altra, una vegada i una altra, una vegada i una altra, etc. Ser conscient que el que estàs fent no té sentit." Una altra obra de De Maria, i més en referència al nostre tema, era cavar un forat i omplir-lo cíclicament. En relació amb l'activitat, el més important, deia l'artista, és "anar amb compte que l'activitat escollida sigui massa agradable, ja que el mínim plaer possible suposa el propòsit del treball" (Comeron, 2007, p. 253) (En aquest cas, veiem un sentit completament diferent del que mostrava l'enterrador de JFK.)

Trobem punts en comú, i es retorna a l'acció de cavar, en un vídeo, Sense Títol (1998), de la parella d'artistes Helena Cabello i Ana Carceller, on podem veure, des d'una visió zenital, dues mans de persones diferents que excaven dos forats a la terra i que, fent servir la terra que ha extret l'altre, després, els tapen. L'acció es va repetint cíclicament i sembla que tot torna a ser com abans, però la terra ha canviat de lloc i canviarà una vegada i una altra d'ubicació, si anem fent aquesta tasca. El sentit poètic rau en el desplaçament de terres, en l'absència $i$ en la renovació, cosa que evoca el treball en equip i la vida en comú habitual en les obres de les dues artistes.

Lara Almarcegui va realitzar un forat en un solar d'Amsterdam. Quan Almarcegui parla de l'obra Cavar (Amsterdam, 1998), no dubta a explicar el seu interès per l'acció: l'acte de cavar en si mateix. Almarcegui no cercava un resultat, s'interessava pel procés i l'experiència absurda d'una acció, encara que gens innocent pel context urbà. Sense saber quan s'interrompria el treball, el projecte es va donar per acabat quan un dia es va trobar el forat tapat per les 
excavadores. Les fotografies de l'acció són els documents que queden del treball de l'artista.

Per la seva part, el col-lectiu artístic austríac Gelitin va cavar i omplir un forat gegant a la platja de Coney Island. L'acció The Dig Cunt (2007) es va repetir durant set dies. Els membres del grup descrivien el treball de la manera següent:

Anem a cavar un forat a la sorra, de set hores d'excavació, a la tarda el tornem a tapar i hi saltem per damunt. Cansats i sense armes, anem a agafar el tren de tornada a Manhattan, per descansar per al dia següent. L'endemà, altre cop agafem el tren cap a Coney Island i cavem un forat per després tapar-lo de nou. (Gelitin, 2007)

Per al col·lectiu, el forat esdevé un monument antifàl·lic, en contraposició als habituals monuments públics erectes. D'aquesta manera, no amaguen les clares referències a artistes dels anys seixanta com Robert Smithson, Michael Heizer o Claes Oldenburg. Especialment, es fa referència a l'obra Placid Civic Monument (1967), de Claes Oldenburg, al Central Park de Nova York, una rasa que remet a la tomba, realitzada per un excavador. Aquest treball, definit per Smithson com anti-monument, s'emmarcava en un context intens i convuls, a causa de l'assassinat del president, la Guerra del Vietnam i les creixents protestes i mobilitzacions ciutadanes.

Hem de tenir en compte que l'ús d'eines i utensilis tecnològics és important a l'hora de fer un forat. Smithson hi fa referència a l'article sobre els earthworks (Smithson, 1968), i parla de la preferència que tenen certs artistes per les eines comunes, les pales, i pels artefactes per a l'excavació d'aspecte groller, també pels tractors i pels aparells d'excavació, les broques, els trepants i els explosius que poden produir pous i terratrèmols.

Aquesta fascinació es veu palesa en l'alteració de l'escorça terrestre que provoquen les intervencions artístiques de Michael Heizer. Un exemple clar és l'obra Double Negative (1969/1970), que concretament es tracta de dues enormes rases d'un quilòmetre i mig realitzades per aplanadores al desert de Nevada (Estats Units). Però Heizer també altera el teixit urbà en l'obra Bern Depression (1969), instal lada a l'exterior de la Kunsthalle de Berna (Suïssa), en el marc de l'exposició «Live in Your Head. When Attitudes Become Form: Works, Concepts, Processes, Situations, Information». L'obra va consistir a colpejar vint vegades el paviment del carrer amb una bola de demolició, cosa que va provocar un accident al terreny artificial.

Però, potser, dins la tradició d'artistes que treballen a partir del forat, Gordon Matta-Clark en sigui el més paradigmàtic i el que s'interessa més 
clarament per intervenir en el teixit urbà allunyant-se del Land Art. L'artista actua sobre edificis, habitualment construccions abandonades, en ruïna o a punt de ser demolides, en les quals obre orificis, talla i disseca la seva arquitectura. Per dur a terme l'obra Conical Intersect (1975), realitzada a la Biennal de París, Matta-Clark va intervenir en un parell d'edificis del segle xvii del carrer de Beaubourg que en aquells anys estaven afectats pel pla de renovació urbanística del barri de Les Halles (París). L'artista detalla la proposta en el text següent:

Se practicó un hueco de forma cónica y se retiró su contenido de las estructuras, de modo que su base en la fachada norte tuviera un diámetro de cuatro metros que iba disminuyendo al travesar la cubierta y la buhardilla del edificio adyacente. El eje central del hueco debía situarse en un ángulo de 35 grados desde el centro del Beaubourg. Todo ello para que los transeúntes pudieran echar un vistazo través del hueco. (Matta-Clark, 1975)

Un cas de forat horitzontal realitzat a l'espai íntim és el que tracta el vídeo Melancholia (2013) (figura 6), de l'artista brasiler Marcelo Salum. El vídeo ens mostra de manera literal l'enderroc d'una paret a l'interior d'un habitatge. L'acció comença a l'altre costat de la paret i el so, producte dels cops i la caiguda de runa, és especialment rellevant. Segons l'artista, aquest treball analitza les relacions contradictòries que s'associen amb la sensació de la malenconia. Per fer-ho, utilitza un llenguatge a través del vídeo, que ens presenta una situació real sense els subterfugis de la representació, però l'artista, que fa l'acció, va amb roba interior i guants de goma que provoquen l'estranyament de qui el mira, en una situació esperpèntica.

Retornant a l'acte de cavar com a activitat que remet al treball genèric, és pertinent recordar l'obra Honest Labor (1979), de Chris Burden, en la qual, com a resposta a una invitació universitària per realitzar una conferència, l'artista es va posar a cavar una rasa en un descampat de manera solitària en horari laboral. D'aquesta manera, tractava el treball com a fonament de l'economia política, com a mesura del valor de les coses (Comeron, 2007, p. 48). 
Figura 6. Fotograma extret de "Melancholia", Marcelo Salum, 2013. Font: Imatge cedida per l'artista.

Aquesta obra de Burden ens serveix d'enllaç amb l'obra 3.000 huecos de $180 \times 50 \times 50 \mathrm{~cm}$. cada uno (2002), de Santiago Sierra. Però, com en la majoria de projectes seus, l'artista contracta treballadors per utilitzar el seu cos i el seu temps de manera crua a canvi del salari mínim. En aquest cas, jornalers immigrants van realitzar tres mil forats en uns camps de la província de Cadis.

Amb un sentit molt diferent del treball de Sierra, trobem l'acció Cuando la fe mueve montañas (2002), de Francis Alÿs, en la qual el joc i el rumor són els catalitzadors que engeguen una acció que involucra una comunitat. L'energia col·lectiva serà el motor principal de la producció. L'11 d'abril de 2002, Alÿs va convocar cinc-centes persones als afores de Lima (Perú); les féu formar en filera al costat d'una duna de cinc-cents metres de diàmetre $\mathrm{i}$ traslladar-la amb pales a una distància de deu centímetres del seu emplaçament original.

Una altra obra que gira al voltant del treball és Geòrgia \& altres qüestions (2009) (figura 7), de Xavier Ristol. L’obra consta de fotografies, un vídeo i un text teatralitzat. El material resultant documenta l'acció de cavar un forat $i$ les situacions que es generen entre l'autor i els dos obrers -immigrants il-legals georgians. Per a l'obra, Ristol demanà als dos obrers de cavar una fossa en un descampat al costat d'una antiga fàbrica en desús. A partir d'aquest moment els obrers 
(...) es representen en un assaig d'excavació arqueològica absurda que no sembla portar enlloc. Es deixen dirigir donant lloc a una simulació de la seva realitat laboral. A mesura que el temps i que les converses se succeeixen, troben xatarres amb les quals especulen i que els permeten remetre's a històries personals i col·lectives. Mentrestant, van sorgint comentaris, fortuïts i casuals, que acaben per mostrar les seves desigualtats socials i polítiques. (Cantalozella, 2012)

Els fets de cavar i d'enterrar serveixen a Núria Güell, en l'obra Resurrecció (2013) (figura 8), precisament per posar al descobert uns fets. La peça consta d'un arxivador amb fotocòpies de fotografies de diferents exhumacions - que l'espectador es pot endur - i es relaciona amb la projecció d'un vídeo d'una acció que representa l'acte de fer un forat i el d'enterrar uns objectes. La gravació causa suspens i intriga. Les propostes de Güell furguen els límits de la legalitat. En aquesta ocasió, l'artista crea una societat amb noms de guerrillers catalans assassinats per les tropes franquistes, i amb una targeta de crèdit a nom d'un d'aquests personatges realitza una compra d'objectes de la Fundación Nacional Francisco Franco que no ha arribat a pagar — com si es tractés d'una mena de confiscació de la mercaderia d'ideologia franquista per a la milícia, la qual farà desaparèixer en una cuneta.

El treball de Güell posa en tensió l'acte de cavar des de dues perspectives antagòniques. Per un costat, el gest d'enterrar fa referència al fet d'ocultar, fer desaparèixer objectes o cossos. Per altre costat, desenterrar evoca els crims comesos que han estat invisibilitzats i les exhumacions de fosses comunes de la Guerra Civil espanyola.

Cal dir que l'acció d'enterrar-se és una activitat present en obres artístiques dels anys setanta, habitualment de caràcter performàtic i conceptual. Per exemple, el treball Self burial (Television Interference Project) (1969), de Keith Arnatt, una performance en la qual l'artista indaga en la desmaterialització de l'art, alhora que l'autor també desapareix, en aquest cas entre la terra. L'obra consta d'una sèrie de nou fotografies en què es veu Arnatt en diferents posicions dins la terra fins a desaparèixer. Aquestes imatges estàtiques van ser emeses per la televisió alemanya WDR 3 al llarg d'una setmana, durant dos segons i en diferents franges horàries, intervenint l'emissió habitual del mitjà de la cultura de masses per excel·lència. 


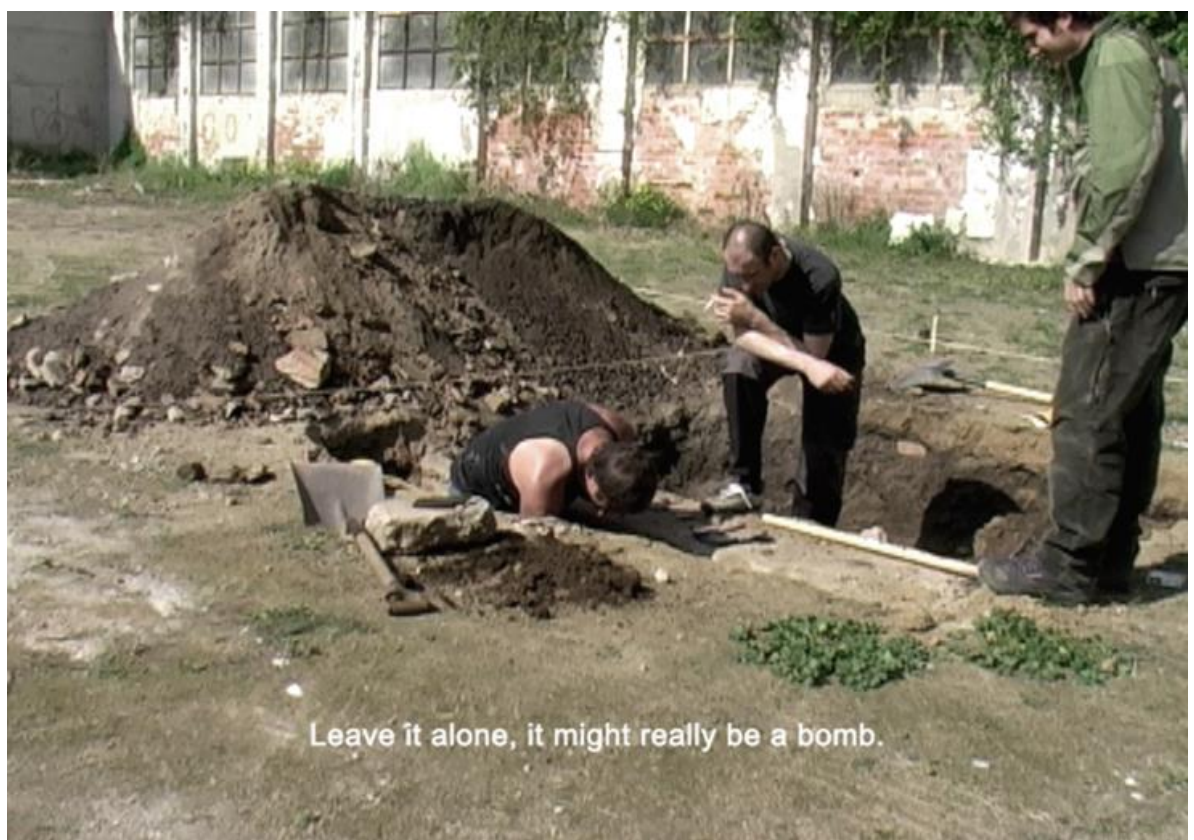

Figura 7. Fotograma extret de Geòrgia \& altres qüestions, Xavier Ristol, 2009. Font: Imatge cedida per l'artista.

En el context català, l'artista Fina Miralles també va realitzar una acció en què el seu cos es planta a terra. En l'obra Dona-Arbre (1973), Miralles s'enterra fins a mitja cama en un camp llaurat, cosa que evoca el fet de brotar del cos, de la dona, en un camp fèrtil. Aquesta imatge està en consonància amb les reivindicacions dels anys setanta, en què confluïen el feminisme i les preocupacions mediambientals, bases de l'actual discurs creixent ecofeminista. (Viladomiu, 2011) 

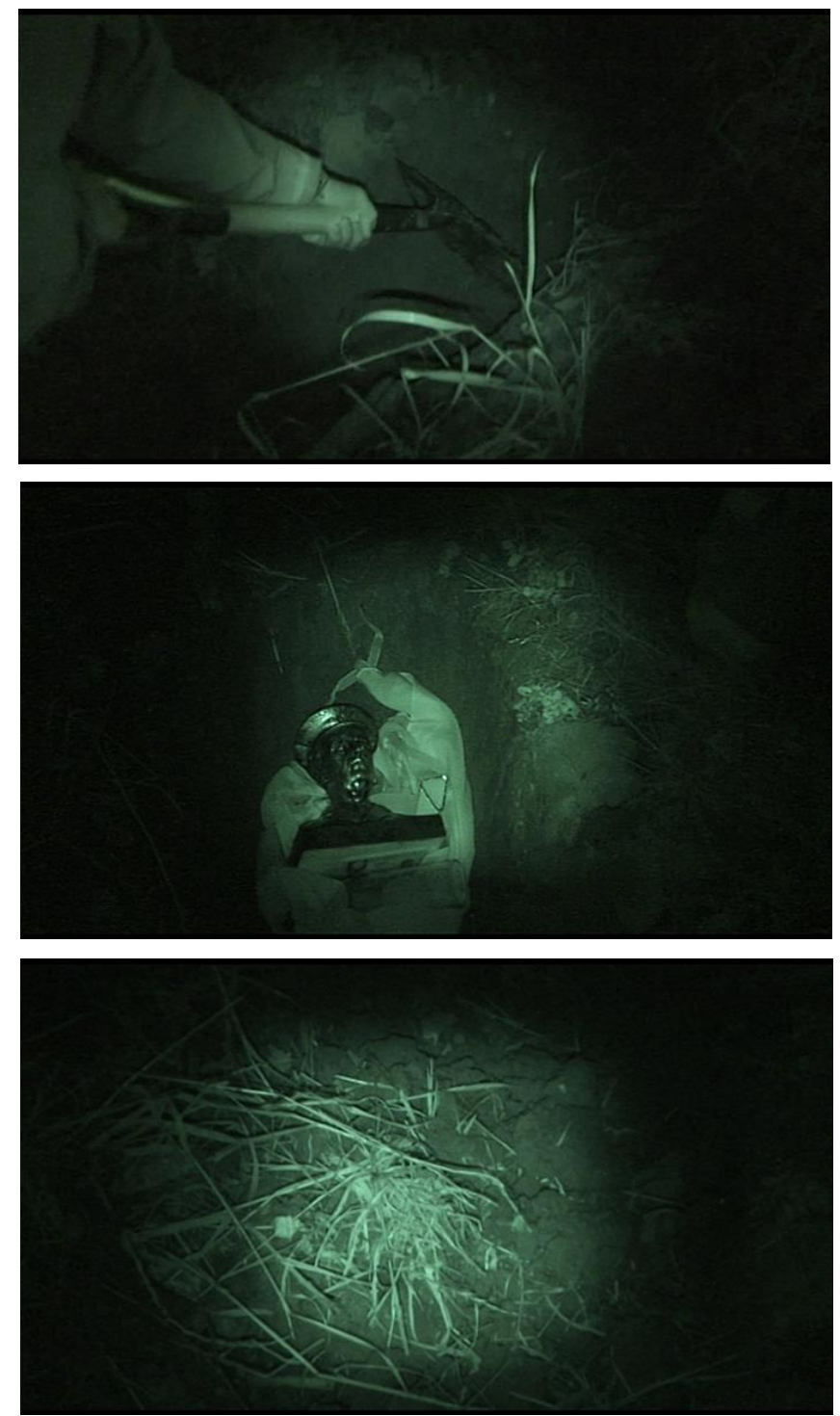

Figura 8. Tres fotogramas extrets de Resurrecció, Núria Güell, 2013. Font: Imatge cedida per l'artista. 


\section{Recapitulació i Conclusions}

En l'article s'indaga, entre situacions literals i d'altres de metafòriques, en la relació de la persona amb el forat. Es fa èmfasi, per una banda, al cos reclòs $i$ que es troba suspès en un interval temporal $i$, per altra banda, a l'acte de cavar com a emblema del treball, així com de l'absurd. La literatura, el cinema i l'art tracten aquests fets des de múltiples vessants, que esdevenen al·legories existencials sobre la persona.

Malgrat les sensacions oposades que pot evocar la reclusió d'un cos (protecció o confinament i sepultura), l'obra de Gregor Schneider ens remet a cambres amb fortes càrregues psicològiques. Entre la presó i la cova, ens emplaça a sensacions d'ansietat i d'opressió que també fan referència a situacions reals extremes, com són segrestos i reclusions en zulos - llocs hermètics $\mathrm{i}$ sense referències cartogràfiques - o bé treballs d'explotacions mineres i accidents laborals, com el cas mediàtic dels trenta-tres miners d'Atacama.

La majoria d'aquests llocs, habitualment soterrats, els imaginem asfixiants en relació amb el cos i ens evoquen la mort en vida. Talment com en un mise en abîme, la imatge de la persona sota terra al-ludeix a diferents sentits d'opressió. Des de l'individu reclòs en un espai reduït i claustrofòbic fins a la violència del treball, la resignació per part de l'individu i la seva dominació: formes fonamentals d'instrumentalització de la subjectivitat.

D'altra banda, es qüestiona l'experiència del temps cronològic lineal. El cos és qui revela el temps, mostrant-lo a través del seu cansament, les seves esperes i la tensió constant que suposa l'expectativa que "alguna cosa ha de succeir". Sense esdeveniment no hi ha temps i sense temps no hi ha vida ni història. Per això, el temps d'una espera no és un consum de temps, sinó un fer temps, és un temps que no compta, que està fora d'un mateix. Paradoxalment, aquest temps d'espera no es deixa perdre, sinó que esdevé "treball immaterial", en tant que activitat productiva vinculada al coneixement (activitats culturals) i a la comunicació (Comeron, 2007, p. 66). En aquest sentit, és explicatiu el succés dels trenta-tres miners d'Atacama, que van convertir la seva reclusió en productes de consum, com és la publicació d'un llibre que un dels miners ha escrit sobre la seva experiència o la pel-lícula filmada en paral·lel mentre es trobaven encara sota terra. Darrerament es va estrenar la producció cinematogràfica The 33 (2015), dirigida per Patricia Riggen, basada en aquests fets.

En un incís s'ha fet referència a tres obres que posen la mirada a coves en l'entorn natural. Les coves d'Herzog, Subirah i Aranberri qüestionen la 
separació entre cultura i naturalesa. Tant en el film d'Herzog sobre la cova de Chauvet com en el projecte sobre el Cau del Duc de Subirah, els artistes fan ús d'artefactes tecnològics de darrera generació per aconseguir l'enregistrament i l'anàlisi minuciosa i rigorosa de les cavitats. A la cova d'Iritegi, Aranberri proposa una alteració de l'espai natural amb el tancament de l'orifici d'entrada, sense cap finalitat pràctica ni com a mesura de protecció. Recordem que a la cova de Chauvet sí que ha estat restringida l'entrada al públic. Les tres propostes, amb processos laboriosos i específics, han propiciat relacions mentals o emocionals amb els indrets en qüestió. Aquestes conviden a pensar que les coves condensen temps, història, però també proposen rumors en llocs on conviuen múltiples vivències, individuals i col-lectives.

Finalment, recordant l'ambivalència que pot suggerir la persona fent un forat, s'ha fet una deriva entre un seguit d'obres artístiques clarament performàtiques o de caràcter conceptual, en què el fet de cavar, perforar, enterrar o desenterrar esdevenen pràctiques comunes entre artistes de diferents generacions i contextos, alhora que s'evidencien significats i intencions diversos. Per exemple, en la rasa de Claes Oldenburg trobem evocacions a la sepultura d'un cos, i esdevé símbol de l'antimonument commemoratiu en la situació convulsa de finals dels seixanta a l'Amèrica del Nord. Els artistes Keith Arnatt i Fina Miralles s'enterren en dues obres, però mentre Arnatt indaga la desaparició de l'autor i altera la programació televisiva, Miralles fa referència a preocupacions mediambientals i a reivindicacions de la dona en el context espanyol dels anys setanta.

El fet de cavar sense cap finalitat aparent que no sigui el mateix cavar el trobem en el col-lectiu Gelitin i en Lara Almarcegui. Les dues propostes giren al voltant de fer un forat sense cercar uns resultats concrets, cosa que mostra la importància tant del procés com de l'experiència absurda de l'acció. Però ambdues propostes no són gens innocents, ja que les seves intervencions generen discontinuïtats en el dia a dia dels veïns del solar o dels usuaris de la platja. Habitualment, aquestes accions produeixen desconcert, són generadores de rumors o, simplement, tenen una voluntat de provocar, de manera crua o bé poètica, els seus espectadors.

També dins un context urbà $i$ amb la voluntat d'alterar la seva trama, Gordon Matta-Clark realitza obertures i alteracions de l'arquitectura. Així mateix, l'acció d'enderrocar un mur present en l'obra de Marcelo Salum ens suggereix la introspecció de l'autor i l'alteració del seu espai més íntim.

D'altra banda, tant la idea de joc com la del rumor són els catalitzadors que impulsen la proposta de Francis Alÿs, una acció absurda que involucra una comunitat de persones per cavar i moure una duna. En l'obra de Xavier Ristol, 
una excavació en un solar també és generadora de situacions, però en aquest cas són entre l'autor i els dos obrers en situació il·legal que realitzen la feina. Durant el procés de treball, afloren comentaris i especulacions amb relació a la feina proposada per l'artista, com també sobre les desigualtats socials i polítiques entre els altres dos actors implicats.

Amb unes intencions més crítiques en els seus contextos sociopolítics, les obres vistes de Chris Burden i Santiago Sierra giren entorn del treball i del treballador. Si en l'acció de Burden és el mateix artista qui cava i el seu cavar és condicionat per l'horari laboral, en Sierra el treball recau en immigrants contractats per utilitzar el seu cos i el seu temps per realitzar uns forats de manera crua a canvi del salari mínim.

En darrer lloc, el fet de cavar en l'obra de Núria Güell posa en tensió dues perspectives antagòniques: el gest d'enterrar i ocultar i el de desenterrar i fer visible. Ho fa de manera física enterrant objectes de caràcter simbòlic, però també ho fa metafòricament pel que fa a qüestions avui encara no resoltes de fets traumàtics de la Guerra Civil espanyola i de la repressió franquista.

En definitiva, per a tots aquests artistes, cavar significa una acció entre absurda i reivindicativa que pot fer emergir uns fets o activar unes situacions que semblen sedimentades tant en el terreny com en la mateixa societat.

\section{Notes}

${ }^{1}$ També en trobem l'adaptació cinematogràfica, Suna no onna, del director Hiroshi Teshigahara (Japó, 1964).

2 «Unter der Erde. Von Kafka bis Kippenberger», exposició comissariada per Marion Ackermann, Kathrin Beßen i Florence Thurmes, a la K21 Ständehaus, dins el marc de la Quadriennale Düsseldorf 2014.

\section{Referències}

Abe, K. (1989). La mujer de la arena. Madrid: Siruela.

Breslin, J. (1963). Cavar la tumba de JFK fue un honor. Dins Letras Libres, núm. 71 (agost 2007). Consultat des de http://www.letraslibres.com/revista /convivio/cavar-la-tumba-de-jfk-fue-un-honor

Camus, A. (1987). El mite de Sísif: Assaig sobre l'absurd. Barcelona: Edicions 62. 
Cantalozella, J. (2012). Cuestiones sobre la alteridad en el trabajo de Xavier Ristol. Revista Estúdio, 3 (5). Lisboa: Faculdade de Belas-Artes da Universidade de Lisboa; Centro de Investigação e Estudos em Belas-Artes. Comeron, O. (2007). La fábrica transparente: Arte y trabajo en la época postfordista (Tesi doctoral). Universitat de Barcelona, Catalunya.

Gelitin (2007). The Dig Cunt. Intervenció a la platja de Coney Island (Nova York, EUA). Consultat des de http://www.gelitin.net/projects/dig_cunt

Güell, N. (2013). Resurrecció. Consultat des de http://www.nuriaguell.net/

Kafka, F. (2000). La guarida. Dins J. R. Hernández (Trad.), Cuentos completos (textos originales). Madrid: Valdemar.

Loers, V. (Comp.) (2011). Punto muerto: Gregor Schneider (catàleg d'exposició). Madrid: Centro de Arte Dos de Mayo de Móstoles.

Lynch, T. (2004). El enterrador: La vida vista desde el oficio fúnebre. Bogotà: Alfaguara.

Matta-Clark, G. (1975). Etant d'Art pour Locataire. Dins G. Moure (Comp.) (2006). Gordon Matta-Clark. Madrid: Museo Nacional Centro de Arte Reina Sofía; Barcelona: Polígrafa.

Moriente, D. (2011). Claustrofilias. Dins V. Loers (Comp.) (2011). Punto muerto: Gregor Schneider. Madrid: Centro de Arte Dos de Mayo de Móstoles.

Moure, G. (Comp.) (2006). Gordon Matta-Clark. Madrid: Museo Nacional Centro de Arte Reina Sofía; Barcelona: Polígrafa.

Newman, M. (2007). Jeff Wall: Obras y escritos. Barcelona: Polígrafa.

Perec, G. (2004). Especies de espacios. Barcelona: Montesinos.

Ristol, X. (2009). Geòrgia \& altres qüestions: Obra escrita en tres actes. Barcelona: Ajuntament de Barcelona; CONCA; Generalitat de Catalunya.

Salum, M. (2013). Melancholia. Consultat des de http://www.marcelosalum. com/

Sierra, S. (2002). 33.000 huecos de $180 \times 50 \times 50 \mathrm{~cm}$. cada uno. Dehesa de Montenmedio, Vejer de la Frontera (Cadis). Consultat des de http://www.santiago-sierra.com/200209_1024.php

Sloterdijk, P. (2008). Extrañamiento del mundo. València: Pre-Textos. 
Smithson, R. (1968). Una sedimentación de la mente. Proyectos terrenos. Dins D. Ortega (ed.) (2011). Robert Smithson: Selección de escritos. Ciutat de Mèxic: Alias.

Subirah, E. (2012). Perdre les formes: Segon exercici. Capella de Sant Antoni, Torroella de Montgrí. Consultat des de http://www.estevesubirah.com/v3/ perdre_les_formes_2_0.php

Viladomiu, À., (2011). Dona-Arbre de Fina Miralles. Dins Revista Estúdio, 2 (4). Lisboa: Faculdade de Belas-Artes da Universidade de Lisboa; Centro de Investigação e Estudos em Belas-Artes.

Dr. Jordi Morell: Profesor del Departamento de Artes Visuales y Diseño. Facultad de Bellas Artes. Universidad de Barcelona.

Email address: jordi.morell@ub.edu

Contact Address: Facultat de Belles Arts. Universitat de Barcelona. Carrer Pau Gargallo 4, 08028 Barcelona. 